\title{
MICROSTRUCTURE AND DAMAGE ASSESSMENT OF SOME PTOLEMAIC POTTERY OBJECTS AT TELL ABU YASIN IN SHARKIA, EGYPT: CASE STUDY
}

\author{
By \\ Walid Kamel cAli 'El-Ghareb \\ Assistant Professor, Conservation Department, Faculty of Archeology, Zagazig University
}

\begin{abstract}
Tell Abu Yasin is one of the most important sites in Sharkia governorate and dates back to Ptolemaic age. Many tests and analyses were performed to diagnose damage manifestations of some pottery pieces. The research has proven that the clay used in that pottery is Nile Clay, while tempers are sand, grog, and limestone powder. The used shaping technology was potter wheel, surface treatment is slip layer, and the burning atmosphere inside the kiln was reduced for the first pot and oxidized to the second and third piece. Pottery objects suffer from physiochemical damage by soil sediments, in addition to phenomenon of fracture, scaling, cracking, weakness, fragility, and crystallization of chlorides, sulfates, carbonates and phosphate salts as a result of burial in saline clay soil. The research recommends that restoration; treatment and maintenance of these pottery pieces should be on the basis of examination results, analyses and damage assessment that have been proven by the researcher.
\end{abstract}

KEYWORDS: Pottery, clay, additives, slip layer, firing atmosphere, damage. 


\section{INTRODUCTION}

Tell Abu Yasin area is located in Sharkia Governorate, it is located $4 \mathrm{~km}$ southeast of Abu Kabir and $40 \mathrm{~km}$ northeast of Zagazig city. It dates back to the Ptolemaic period, where excavations were carried out by the Supreme Council of Antiquities mission revealing many different shapes and colors of pottery pieces, as well as many different kilns, stoves and a cemetery including some granite sarcophagi ${ }^{1}$. Tell Abu Yasin is located within the district of Horbait, and was known by ti -rimo. Its name is derived from the ancient Egyptian name «Hur Bit »and Farpithios in the Greek era². Its current location is the village of Horbit in Sharkia, Egypt ${ }^{3}$.

Pottery is one of the most important types of artifacts for the regional chronology and distribution of cultures, in addition to demonstrating relationships between settlement sites due to difference and diversity of manufacturing techniques, tools, shapes and decoration patterns ${ }^{4}$. Microstructure and tempers play a role in identifying technology of manufacture and classification of pottery, in which there has been clear progress in the field of examinations and analyses in recent times ${ }^{5}$.

The methods of examination and analysis in the field of study of archaeological materials have differed and varied according to their different objectives ${ }^{6}$ such as micromorphology, mineral composition, structure behavior and thermal characteristics ${ }^{7}$. Microscopic examination of pottery provides information on micro composition and morphology of archaeological samples ${ }^{8}$, while petrographic structure study plays an important role in identifying mineral components, microstructure, shape and size of grains, their relationship with each other and their distribution in the pottery specimen'. Examination and analysis give a clear map of the nature of damage whether it is workmanship defects or soil decay ${ }^{10}$. Pottery pieces suffer from damage due to manufacturing defects such as fine cracks, black core and staining phenomenon as a result of burning process ${ }^{11}$. Many pottery relics such as terracotta have many damage aspects due to manufacture processes. Burning failure leads to rapid surface deterioration for terracotta, and high firing temperatures create glass matrix that my damage pottery products ${ }^{12}$.

Pottery pieces buried in the soil suffer from physiochemical damage that deforms the surface and mineral composition. Damage speed and its rate depend on type of burial

\footnotetext{
${ }^{1}$ NOUREDDINE 2018: 360.

2 CABD 'EL -HAMID 2007: 668- 677.

${ }^{3}$ KAMEL 1981: 161.

${ }^{4}$ TURKTEKI 2020: 59.

${ }^{5}$ HOGG \& AL. 1999: 42.

6 CABDEMMONIEM et AL. 2020: 7-17.

7 BIRDI 2003: 1 .

${ }^{8}$ MABROUK 2020: 165.

${ }^{9}$ BOUKHENOUF 2020: 51.

10 'El-GHAREB 2001 :150- 155.

${ }^{11}$ MIRTI 1998: 45.

${ }_{12}$ ASHURST 1989: 72-73.
} 
environment, whether it is dry or wet burial environment ${ }^{13}$. Pottery pieces suffer from staining phenomenon because of burning or iron deposits in soil of archaeological site. This staining phenomenon increases in porous pottery ${ }^{14}$. Pottery often suffers from phenomenon of fracture due to soil mechanical damage ${ }^{15}$, this phenomenon increases in marine burial environments due to intense water currents ${ }^{16}$. Among the most important damage aspects of pottery buried in the soil is crystallization of salts ${ }^{17}$, cracking and fracture ${ }^{18}$.

The resulting damage is physiochemical deterioration; and fragmentation may occur within a few minutes during excavations ${ }^{19}$. This type of pottery needs restoration, treatment and maintenance process to remove soil sediments, as well as strengthening process that consolidates and links the granules and improves physical and mechanical properties especially using novel nano materials for consolidation ${ }^{20}$.

Therefore, this study aims to determine microstructure, mineral composition and damage assessment of archaeological pottery at Tell Abu Yasin in Sharkia for its treatment and maintenance based on proven results by the researcher.

\section{II.STUDY MATERIALS AND METHODS}

\section{Study Materials}

Four samples were selected; namely three samples of pottery pieces extracted from Tell Abu Yasin in Sharkia (case study), and one soil sample from the archaeological site, all of which were used in examination and analysis conducted for this study.

\section{Study Methods}

\section{A. Visual Examination}

Visual examination method is the first stage of examination process where some lenses and stereomicroscopes with different magnification are used in visual assessment process of pottery samples ${ }^{21}$.

\section{B. Petrographic Examination}

Polarizing microscope is one of the important methods used in studying petrographic structure ${ }^{22}$, mineral changes, function use, tempers, grains size, mineral composition, surface treatment, in addition to glass phases ${ }^{23}$. Thin section was prepared for examination using Nikon Eclipse polarizing microscope. This examination was performed at the Geological Survey in Cairo.

\footnotetext{
${ }^{13}$ FLORIAN 2000:1.

${ }^{14}$ HODGE 1986: 147.

15 PRICE 1984: 4.

${ }^{16}$ HAMITON 1998: 17; PEARSON 2000: 98.

${ }_{17}$ SMITH 1999: 163.

${ }^{18}$ CRONYN 1996: 29.

19 PLENDERLEITH 1971: 125.

${ }^{20}$ CINTEZA ,2012: 28.

21 'El-GHAREB 2017: 76- 77.

22 STOLTMAN 2001: 297- 326.

${ }^{23}$ RIEDERER 2004: 143- 158.
} 


\section{MICROSTRUCTURE AND DAMAGE ASSESSMENT OF SOME \\ PTOLEMAIC POTTERY OBJECTS AT TELL ABU YASIN IN SHARKIA, EGYPT: CASE STUDY}

\section{Scanning Electron Microscopy with EDX Unit}

It is one of the important technologies in the field of examination and analysis of pottery. Scanning electron microscope equipped with EDX unit describes morphology of pottery surface, size of grains, distribution of particles, texture, surface treatment and damage forms such as gaps, cracks, crystallization of salts, peeling and mineral composition of archaeological pottery ${ }^{24}$. The device used is model Quanta FEG250 SEM unit. This examination was performed by scanning electron microscope unit at the National Research Center in Cairo.

\section{XRD analysis}

It gives information about the nature of pottery manufacture technology especially firing process, mineral changes which were caused during manufacture or burial in the soil ${ }^{25}$. The device used is XRD device model Philips Analytical X-Ray; and this analysis was conducted at XRD unit at Center of Microanalysis at Ain Shams University.

\section{E. Thermal Analysis}

Thermal Differential Analysis «DTA» was used to determine firing temperature of pottery due to mineral changes that occurred during firing of pottery ${ }^{26}$. Two pottery samples were analyzed by thermal analysis device Perkin Elmer STA 6000, the temperature program ranged from room temperature to $1500^{\circ} \mathrm{C}$, measurement range: \pm 0.2 to $\pm 1000 \mu \mathrm{V}$, heating speed: 0 to $+50^{\circ} \mathrm{C} / \mathrm{min}$, temperature, and mineral changes were recorded on the chart. This thermal analysis was performed at the Faculty of Science, Cairo University.

\section{Results}

\section{A. Visual Examination}

Visual examination proved that the pottery pots in Tell Abu Yasin in Sharkia suffered from high percentage of clay soil sediments, crystallization of salts, various stains, missing parts, black core, peeling and separation of slip layer. It also proved that forming method was potter wheel method for the first and third piece, as well as coiling shaping method for the second piece as in [FIGURE 1].

\footnotetext{
${ }^{24}$ MORO et AL 2020: 223-232.

${ }^{25}$ CLIMENT et AL 2018: 240.

${ }^{26}$ BAYAZIT et AL 2014: 14769- 14779.
} 

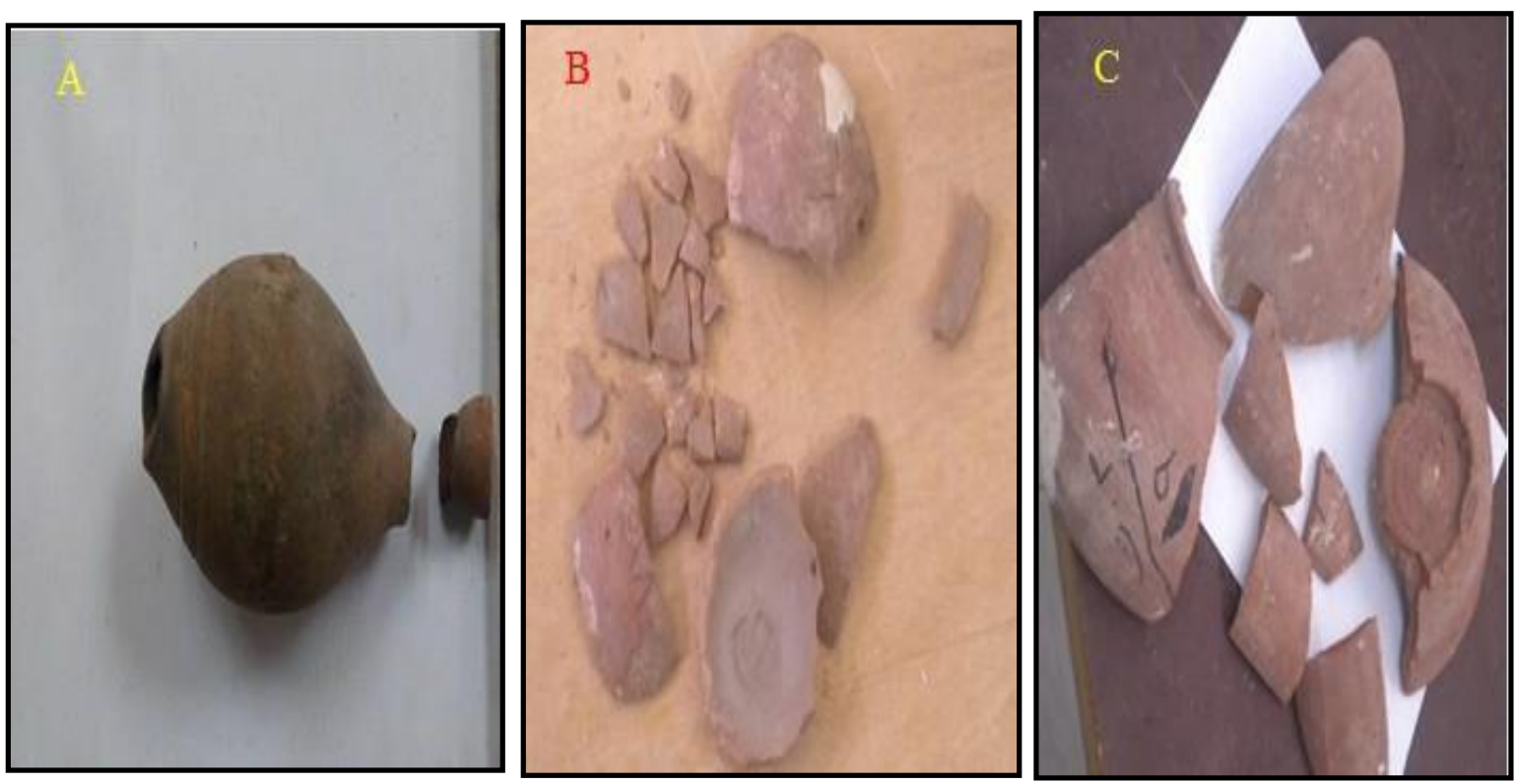

[FIGURE 1]: Pottery pieces at Tell Abu Yasin in Sharkia. A: pot B: plate C: bowl

\section{B. Examination by polarizing microscope}

Pottery samples were examined by polarized microscope as in [FIGURE 2], where surface examination with polarized light showed presence of quartz grains, most of which are fine grains, as well as some coarse quartz grains, some grains are semicircular, others are sharp angular and contain biotite as shown in [FIGURE 2/A]. Another part of the same sample was also examined showed the presence of quartz grains from fine grains to coarse grains, as well as limestone powder, biotite and rutile as in [FIGURE 2/B]. The examination of core showed presence of quartz grains, as well as limestone powder, biotite and rutile as in [FIGURE 2/C]. An examination of another part of core illustrated presence of quartz grains from fine grains to coarse grains, as well as grog, biotite and rutile as in [FIGURE 2/D]. 

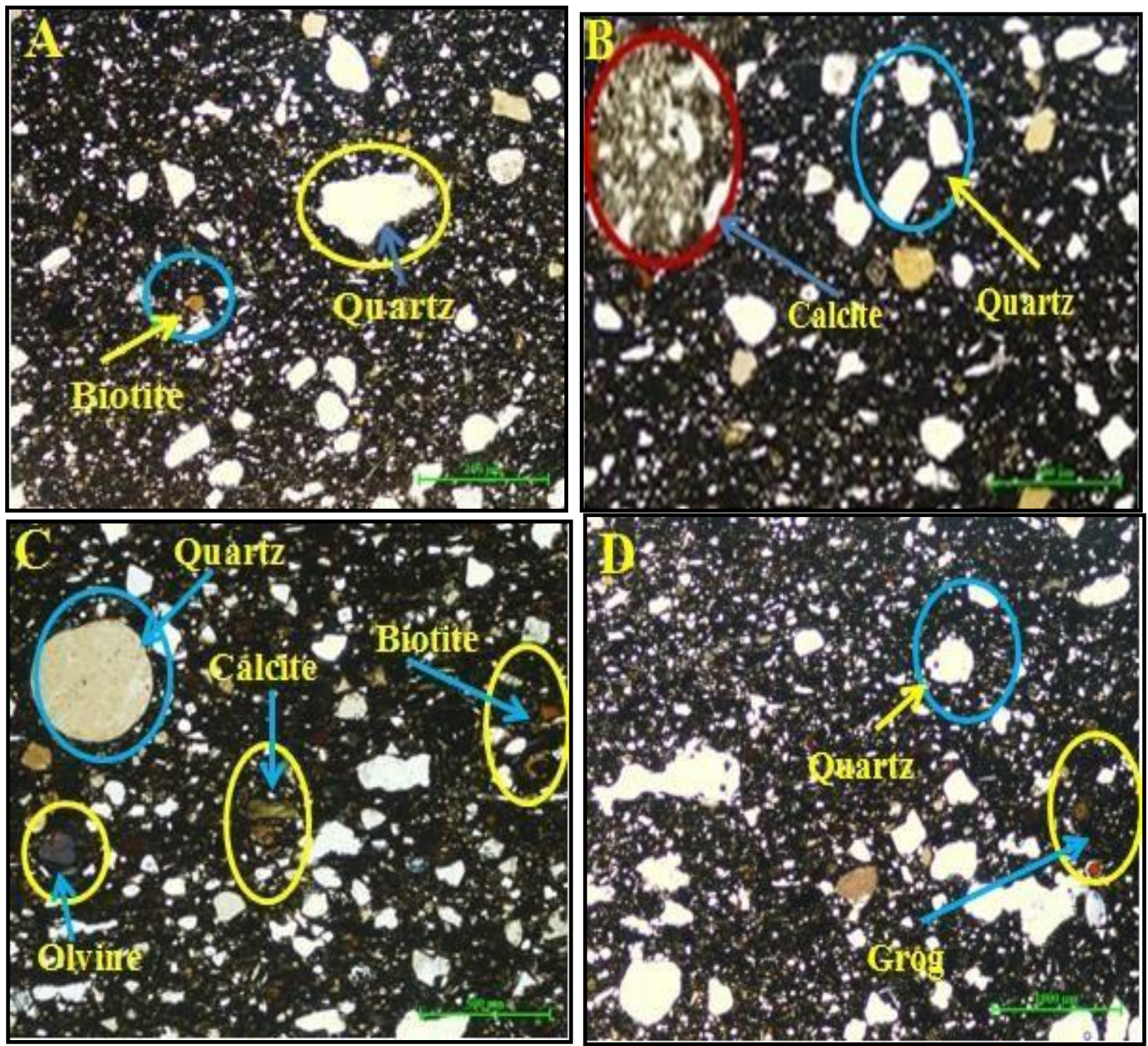

[FIGURE 2]: Petrographic examination of the first sample A: quartz, biotite, rutile. B: quartz, biotite, limestone powder. C: quartz, biotite, calcite \& olvine 
[FIGURE 3]: The second pottery sample showed presence of a delicate texture of quartz granules, in addition to remnants of calcite, pyroxene, burnt straw and rutile as in [FIGURE 3/A]. Examination of another part of the same sample showed presence of fine quartz granules, as well as calcite, biotite, plagioclase, and rutile as in (FIGURE 3/B). The examination of core illustrated presence of fine quartz grains, some quartz grains as one of the additives materials found accidently, as well as calcite, biotite, rutile and burnt straw as in [FIGURE 3C]. The examination «another part of core» also showed presence of fine quartz, calcite, biotite, rutile as in [FIGURE 3/D].
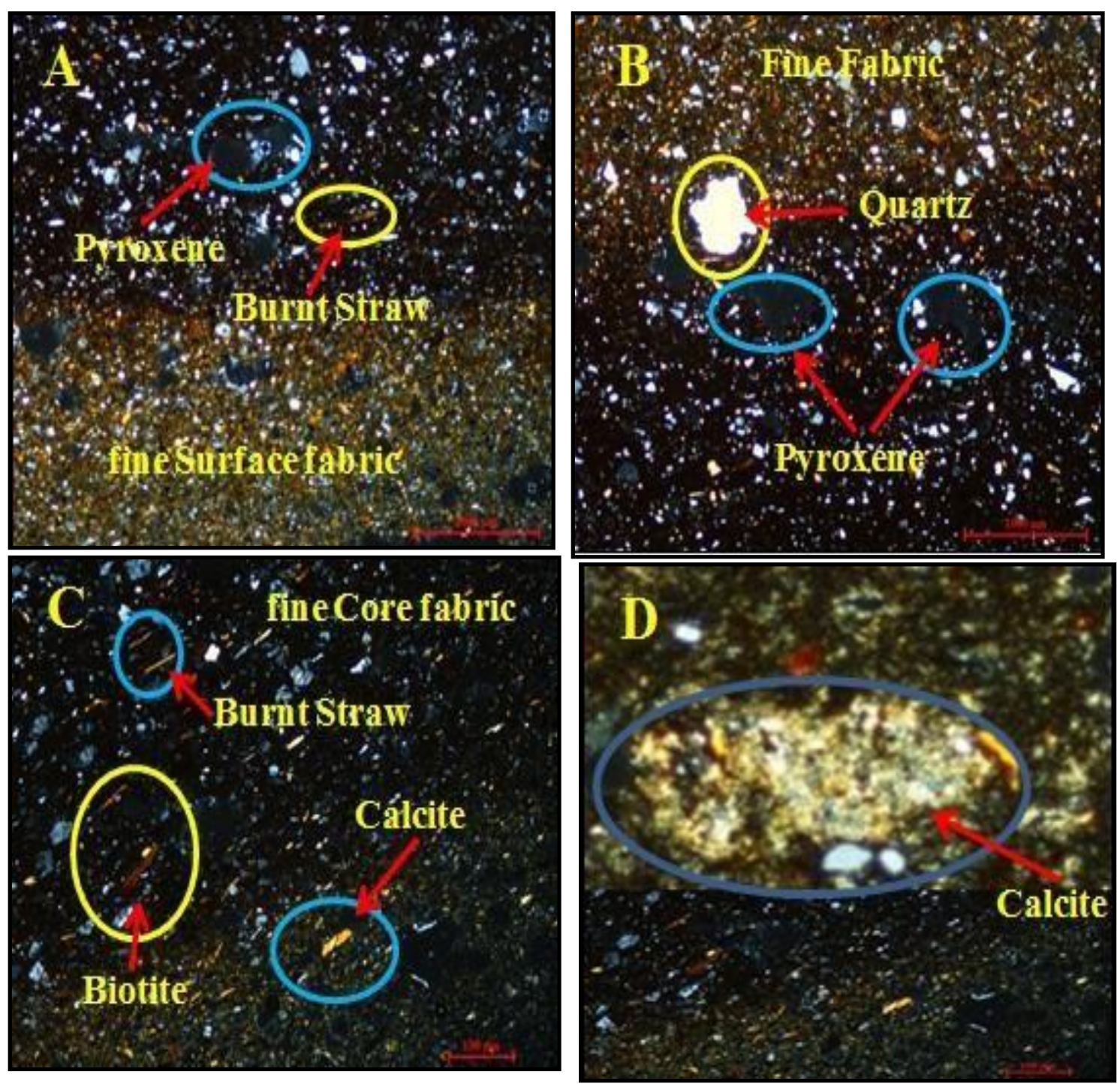

[FIGURE 3]: Petrographic examination of the second pottery sample. A: quartz, calcite, biotite, burnt straw\& pyroxene. B: quartz, calcite biotite\& pyroxene. C: quartz, biotite, calcite, burnt straw \& rutile. D: quartz, calcite, biotite 
For the third pottery sample, [FIGURE 4] showed the presence of fine to medium pottery texture of quartz grains, in addition to calcite, grog and rutile as in [FIGURE 4/A], another part of the same sample was examined showing presence of fine quartz granules, as well as grog, biotite, muscovite and rutile as in [FIGURE 4/B]. The examination of core illustrated presence of fine pottery texture of fine quartz granules, in addition to calcite, biotite, rutile, and burnt straw as in [FIGURE 4/C]. It also showed presence of fine pottery texture of fine quartz grains, as well as presence of calcite, biotite, rutile, and burnt straw as in [FIGURE 4/D].

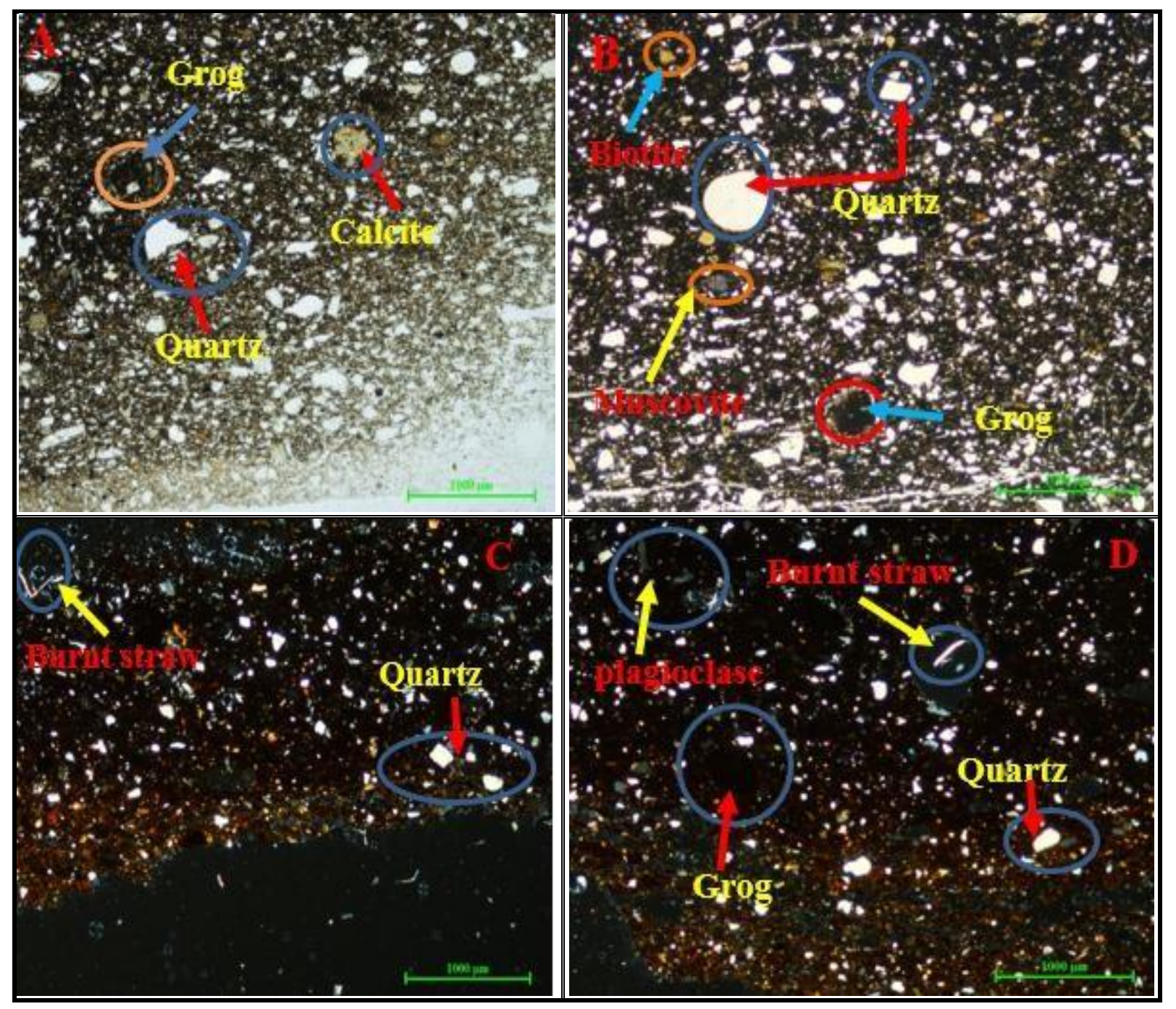

[FIGURE 4]: Petrographic examination of third pottery specimen: A: quartz, biotite \& rutile. B: quartz, grog biotite \& muscovite. C: quartz, biotite, calcite \& burnt straw. D: quartz, calcite, burnt straw, biotite, grog \&plagioclase. 


\section{Examination and Analysis by Scanning Electron Microscope with EDX Unit.}

The pottery pieces extracted from Tell Abu Yasin in Sharkia were examined byenvironmental scanning electron microscope.

\section{- Scanning Electron Microscope Examination}

[FIGURE 5] shows scanning electron microscope examination of the first sample (surface area), where examination showed that the sample suffers from presence of soil sediments as a result of burial in the soil for thousands of years, gaps, cracks, peeling and crystallization of salts [FIGURE 5/A]. Another part was examined for the core area, where examination showed presence of some coarse quartz grains, as well as some gaps, peeling and crystallization of salts as in [FIGURE 5/B].
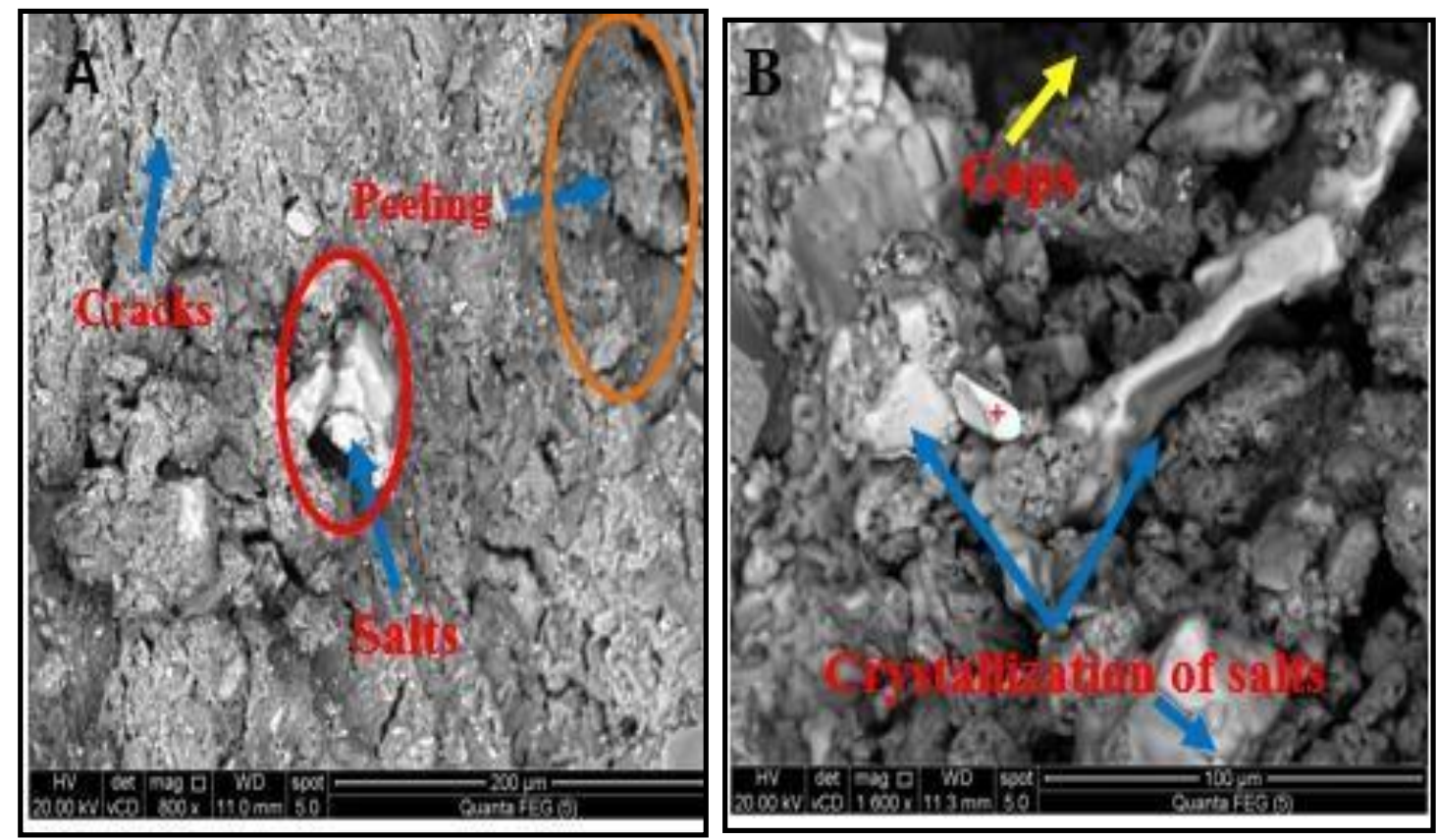

[FIGURE 5]: SEM examination of the first pottery specimen A: SEM examination of surface area (200X), B: SEM examination of core matrix (1600X).

The [FIGURE 6] showed scanning electron microscope examination of the second sample of the surface area, where it was found that the sample suffered from many cracks, gaps and scaling as in [FIGURE 6A]. Another part of core matrix was examined, where examination showed presence of some quartz grains, as well as some cracks, peeling of slip layer and crystallized salts as in [FIGURE 6/B].
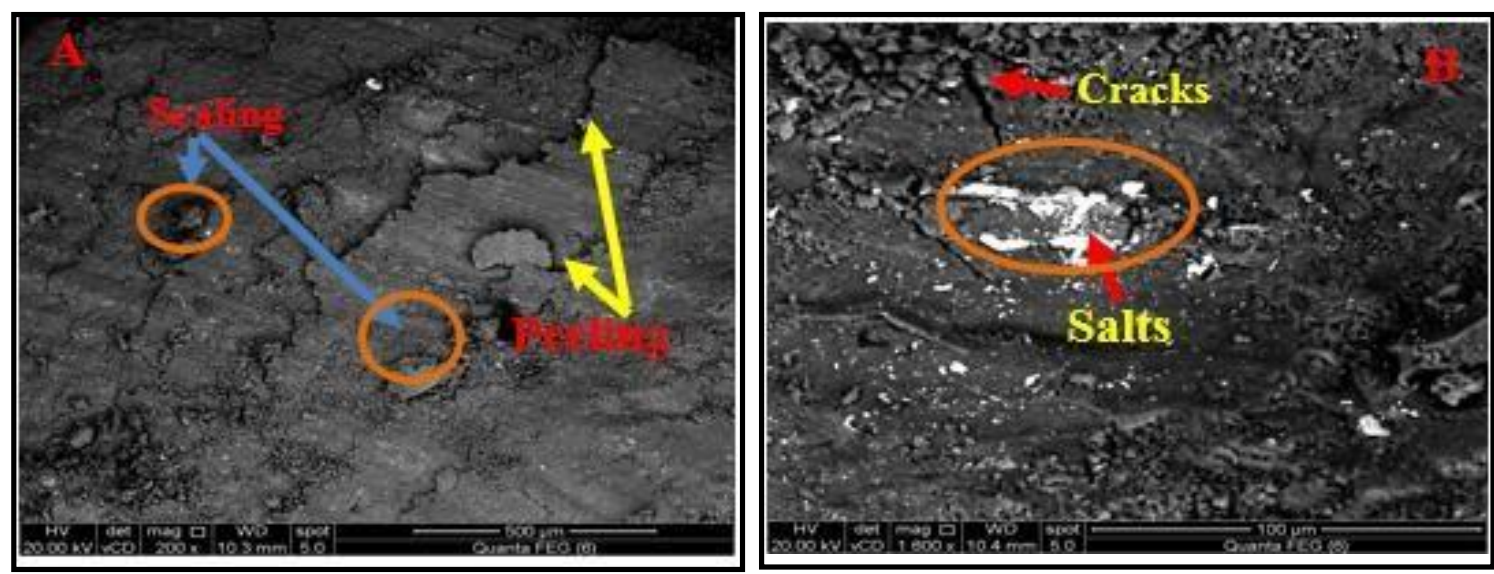

[FIGURE 6]: SEM examination of the second pottery specimen. A: SEM examination of surface area (200X). B: SEM examination of core (1600X). 
[FIGURE 7] represents scanning electron microscope examination of the thirdsample of surface area showing that the sample had a fine texture, as well as presence ofcracks, peeling, and some parts of surface treatment as in [FIGURE 7/A]. Another part of core area was examined, where the examination showed presence of crusting of slip layer, some gaps and crystallization of salts as in [FIGURE 7/B].
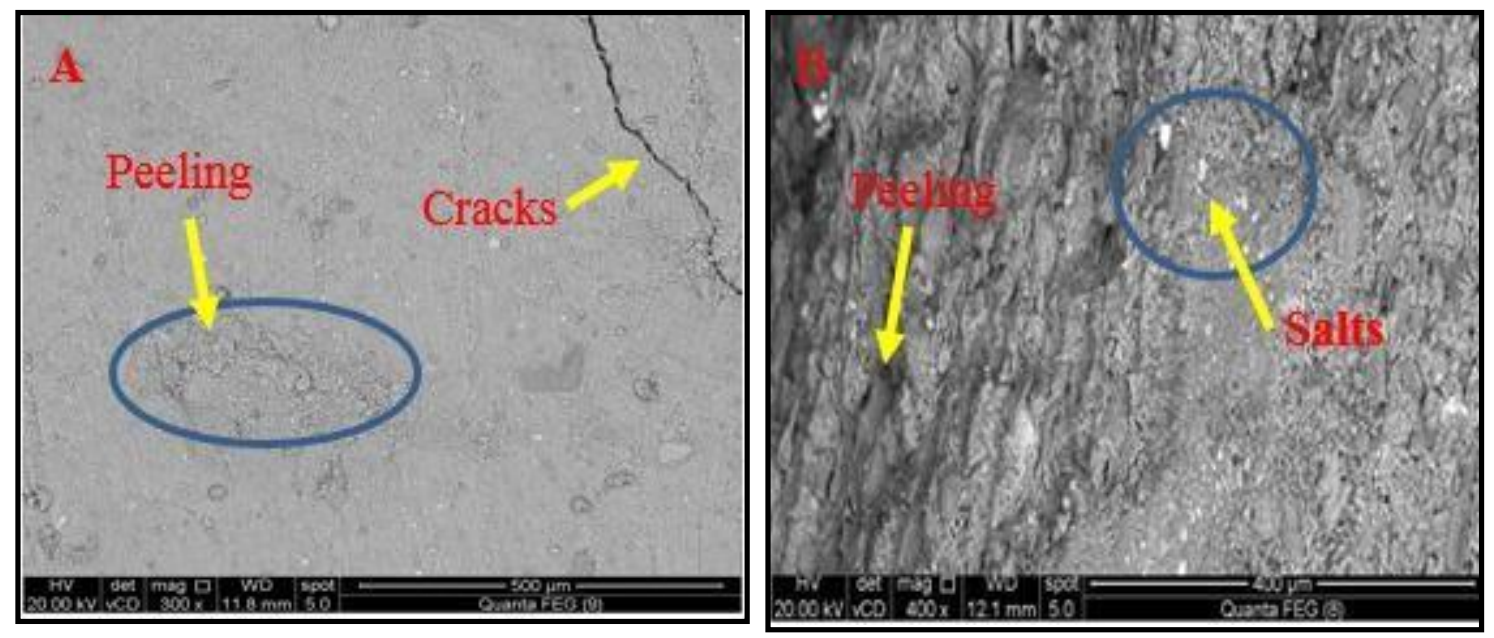

[FIGURE 7]: SEM examination of the third pottery specimen. A: SEM examination of surface area $(300 X)$. B: examination by SEM of core matrix $(400 \mathrm{X})$.

\section{- Scanning Electron Microscope Analysis}

The results of EDX analysis of three pottery specimens for surface and core as shown in [FIGURE 8/A-F] clarified the presence of carbon, oxygen, sodium, magnesium, aluminum, silica, molybdenum, sulfur, chlorine, potassium, calcium, titanium, vanadium and iron. These EDX analytical results for three sample results are shown in [TABLE 1]. 

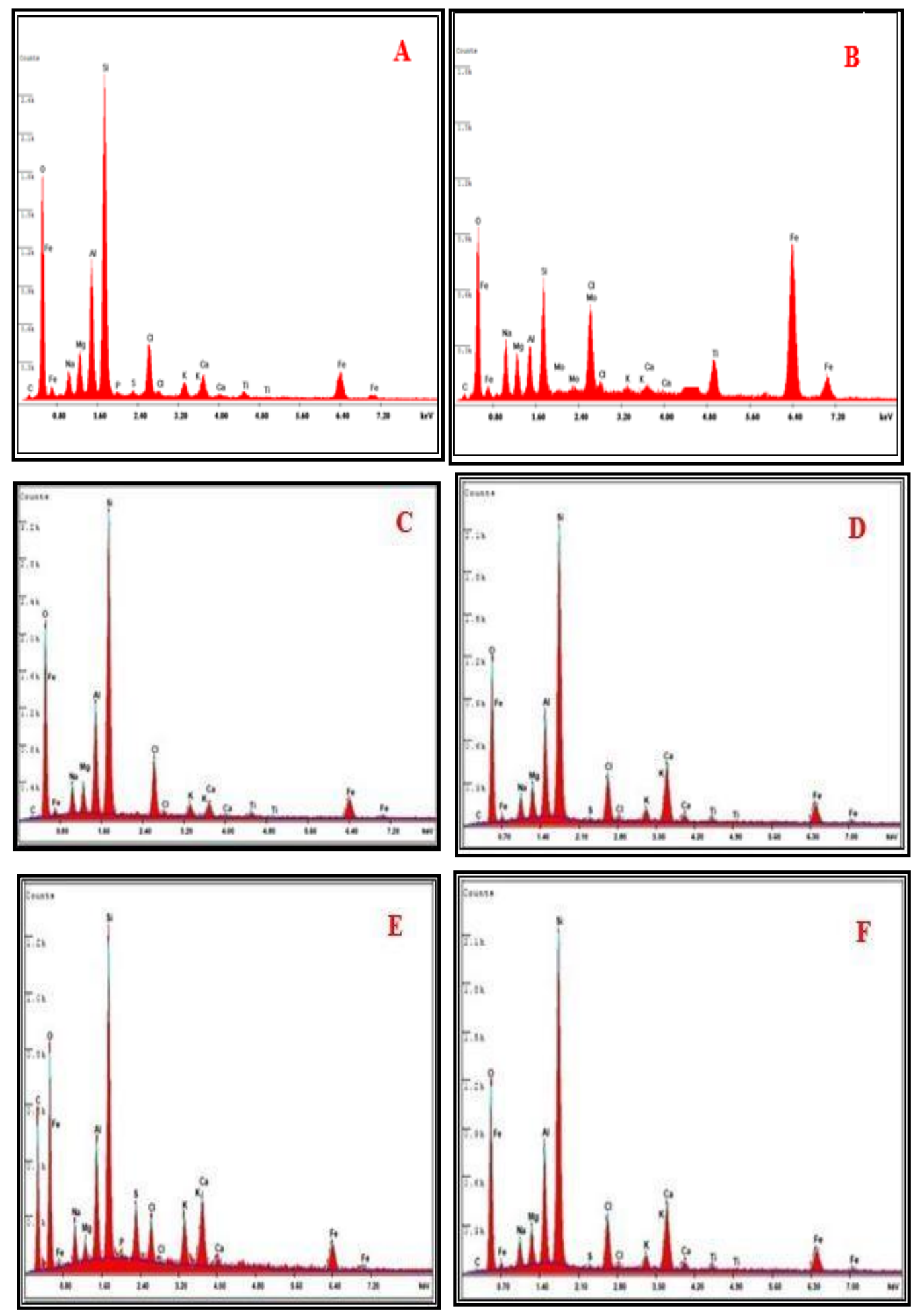

[FIGURE 8]: A-F: EDX analysis patterns of pottery samples, Tell Abu Yasin, Sharkia. A-B: First pottery. C-D: Second pottery. E-F: Third pottery. 
MICROSTRUCTURE AND DAMAGE ASSESSMENT OF SOME PTOLEMAIC POTTERY OBJECTS AT TELL ABU YASIN IN SHARKIA, EGYPT: CASE STUDY

\begin{tabular}{|c|c|c|c|c|c|c|}
\hline & & S1 & & $\mathrm{S} 2$ & & S3 \\
\hline Elemental & & core & surface & Core & Surface & Core \\
\hline Weight \% & Surface & & & & & \\
\hline $\mathrm{C}$ & 5.57 & 1.66 & 1.20 & 1.06 & 2.94 & 26.92 \\
\hline $\mathrm{O}$ & 13.50 & 27.57 & 27.54 & 26.16 & 13.26 & 22.08 \\
\hline $\mathrm{Na}$ & 3.30 & 2.17 & 3.16 & 2.52 & 0.62 & 2.16 \\
\hline $\mathrm{Mg}$ & 1.93 & 3.04 & 2.71 & 2.82 & 0.96 & 0.98 \\
\hline $\mathrm{A} 1$ & 2.15 & 9.87 & 9.67 & 8.60 & 6.32 & 5.35 \\
\hline $\mathrm{Si}$ & 4.22 & 25.85 & 20.05 & 25.68 & 17.27 & 14.95 \\
\hline Mo & 0.57 & - & - & - & - & - \\
\hline $\mathrm{P}$ & - & 0.22 & - & - & 0.15 & 0.31 \\
\hline$S$ & - & 0.39 & - & 0.42 & 0.29 & 3.26 \\
\hline $\mathrm{Cl}$ & 4.26 & 6.09 & 7.70 & 5.92 & 0.32 & 3.90 \\
\hline $\mathrm{K}$ & 0.48 & 2.23 & 2.08 & 2.07 & 6.71 & 4.05 \\
\hline $\mathrm{Ca}$ & 0.68 & 3.39 & 2.68 & 10.26 & - & 6.63 \\
\hline $\mathrm{Ti}$ & 27.57 & 1.52 & 1.45 & 1.24 & 14.56 & - \\
\hline $\mathrm{V}$ & - & - & - & - & 0.26 & - \\
\hline $\mathrm{Fe}$ & 40.41 & 40.41 & 13.81 & 13.18 & 38.31 & 10.37 \\
\hline
\end{tabular}

[TABLE 1]: EDX analytical results of investigated pottery sherds Done by the author. 


\section{- X- Ray Diffraction Analysis}

Three pottery samples and one soil sample from the archaeological site were analyzed byXRD. The pattern of three pottery samples showed presence of quartz $\mathrm{SiO}_{2}$, microcline $\mathrm{KALSi}_{3} \mathrm{O}_{8}$, albite $\mathrm{NaAlSi}_{3} \mathrm{O}_{10}$, halite $\mathrm{NaCl}$, hematite $\mathrm{Fe}_{2} \mathrm{O}_{3}$, Magnetite $\mathrm{Fe}_{3} \mathrm{O}_{4}$, anhydrite $\mathrm{CaSO}_{4}$. Soil sample pattern contained quartz $\mathrm{SiO}_{2}$, microcline $\mathrm{KAlSi}_{3} \mathrm{O}_{8}$, albite $\mathrm{NaAlSi} \mathrm{O}_{10}$, halite $\mathrm{NaCl}$, as shown in [TABLE 2] and [FIGURE 9/A-D].

\begin{tabular}{|c|c|c|c|c|c|}
\hline Minerals & $\begin{array}{l}\text { Chemical } \\
\text { composition }\end{array}$ & $\mathrm{a}$ & $\mathrm{b}$ & $\mathrm{c}$ & $\mathrm{d}($ soil $)$ \\
\hline quartz & $\mathrm{SiO}_{2}$ & 36.6 & 25.9 & 25.2 & 20.5 \\
\hline microcline & $\mathrm{KALSi}_{3} \mathrm{O}_{8}$ & 19.3 & 29.6 & 23.2 & 30.7 \\
\hline albite & $\mathrm{NaAlSi}_{3} \mathrm{O}_{10}$ & 32.1 & 29.5 & 25.6 & 43 \\
\hline calcite & $\mathrm{CaCO}_{3}$ & 6.2 & - & - & - \\
\hline hematite & $\mathrm{Fe}_{2} \mathrm{O}_{3}$ & - & 7.8 & 4.4 & - \\
\hline Magnetite & $\mathrm{Fe}_{304}$ & 3.1 & - & - & - \\
\hline halite & $\mathrm{NaCl}$ & 2.7 & 7.2 & 8.9 & 5.8 \\
\hline anhydrite & $\mathrm{CaSO}_{4}$ & - & - & 12.7 & - \\
\hline
\end{tabular}

[TABLE 2]: XRD analytical results of investigated pottery sherds Done by the author. 

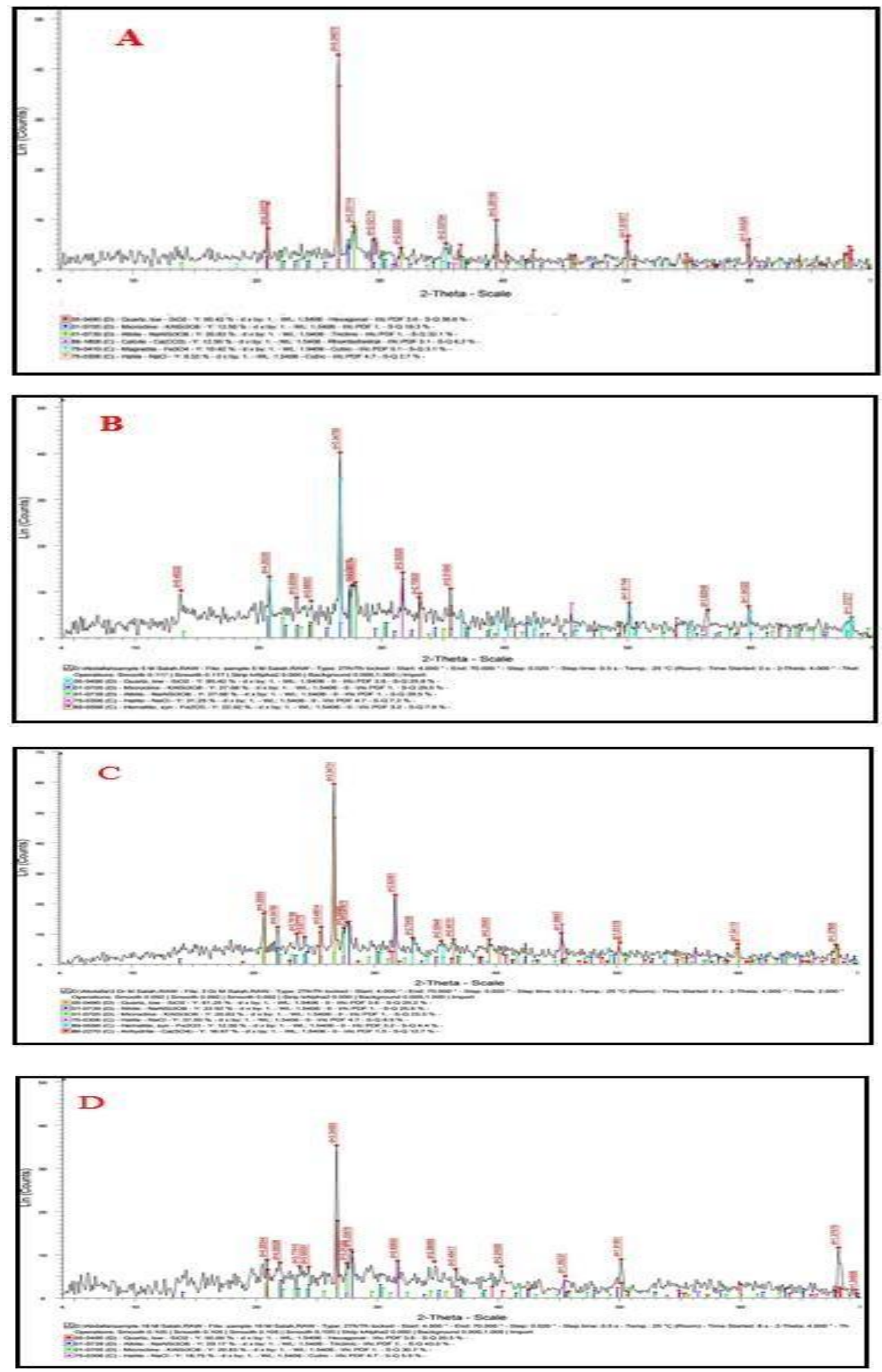

[FIGURE 9]: XRD patterns of three pottery samples and one soil sample, Tell Abu Yasin, Sharkia, Egypt. A: the first pot. B: the second pottery plate. C: the third pottery vessel. D: soil sample. 


\section{- Differential thermal analysis}

Differential thermal analysis «DTA» of the first pottery sample showed slight mineral changes in firing temperature from $94.81^{\circ} \mathrm{C}$ to $178.76^{\circ} \mathrm{C}$.; the mineral changes increased from $406.96^{\circ} \mathrm{C}$ to $705.26^{\circ} \mathrm{C}$, and the stability of the mineral changes occurred in the range from $705.26{ }^{\circ} \mathrm{C}$ to $1000{ }^{\circ} \mathrm{C}$. The results of mineral changes indicated that the firing temperature might have been about $705.26^{\circ} \mathrm{C}$, as in [FIGURE 10].

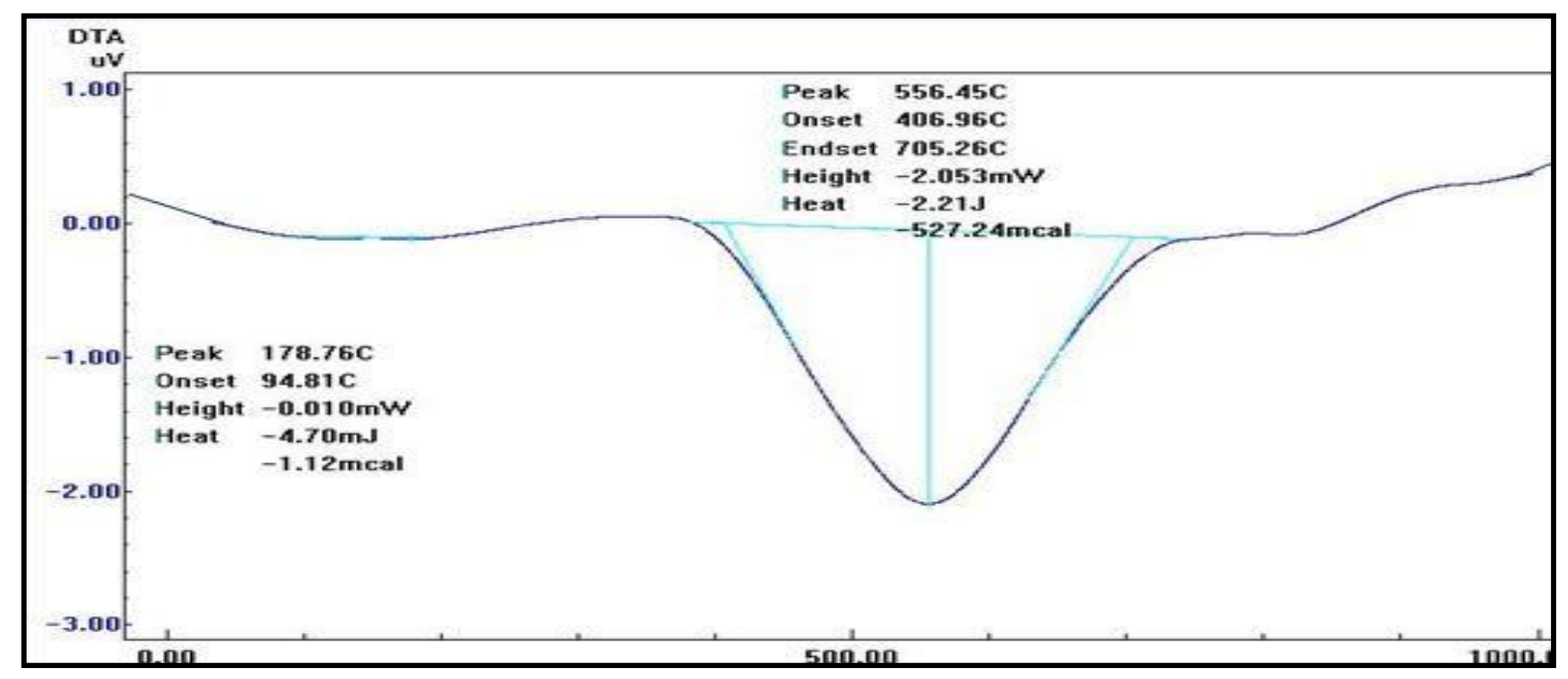

[FIGURE 10]: DTA pattern of the first pottery sample, Tell Abu Yasin, Sharkia, Egypt

Differential thermal analysis «DTA» of the second pottery sample showed slight mineral changes in firing temperature from $24.78^{\circ} \mathrm{C}$ to $84.88^{\circ} \mathrm{C}$, the minerals changes increased from $278.61^{\circ} \mathrm{C}$ to $782.99^{\circ} \mathrm{C}$, the stability of the mineral changes ranged from $782.99^{\circ} \mathrm{C}$ to $1000^{\circ} \mathrm{C}$. The results of mineral changes indicated that the firing temperature might have benabout $782.99^{\circ} \mathrm{C}$ as in [FIGURE 11].

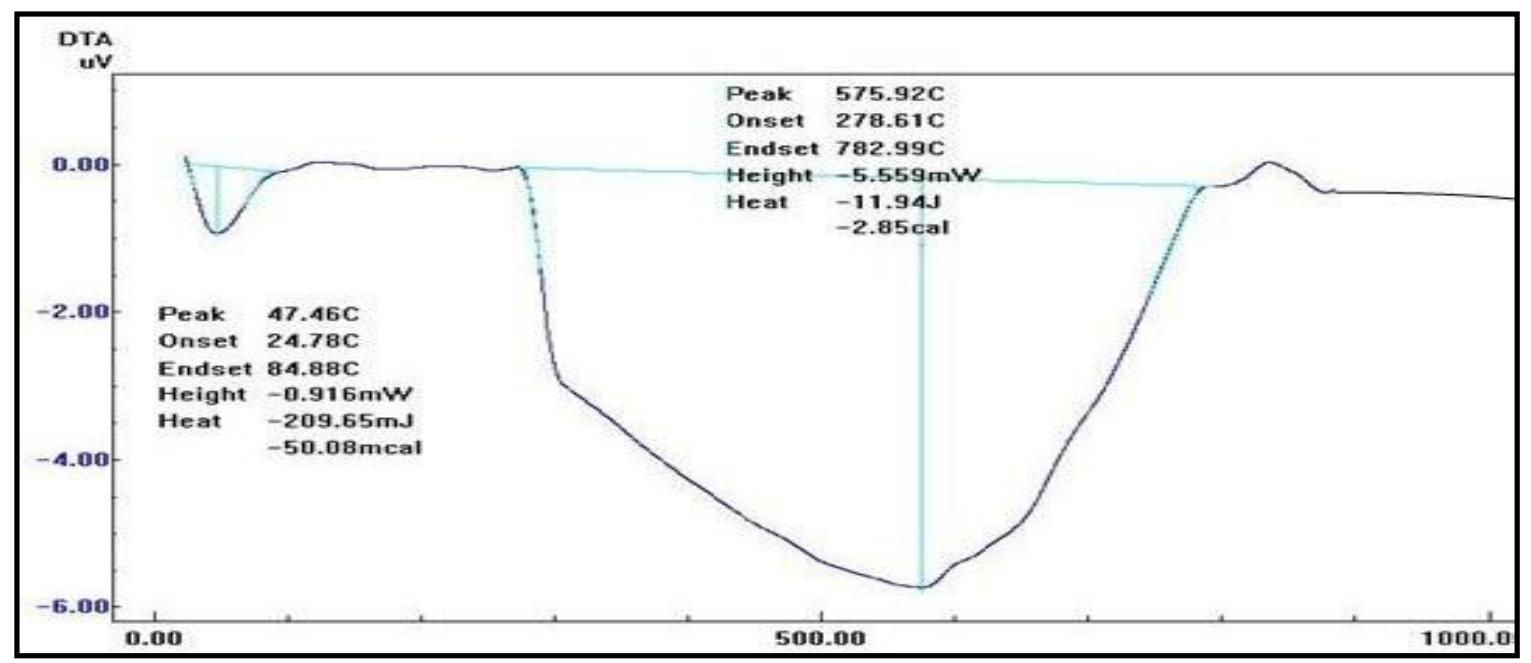

[FIGURE 11]: DTA pattern of the second pottery sample, Tell Abu Yasin, Sharkia, Egypt

Differential thermal analysis «DTA» of the second pottery sample showed slight mineral changes in firing temperature from $24.78^{\circ} \mathrm{C}$ to $84.88^{\circ} \mathrm{C}$, the mineral changes increased from $278.61^{\circ} \mathrm{C}$ to $782.99^{\circ} \mathrm{C}$, the stability of the mineral changes ranged from $782.99{ }^{\circ} \mathrm{C}$ to $1000{ }^{\circ} \mathrm{C}$. The results of mineral changes indicated that the firing 
temperature might be about $782.99^{\circ} \mathrm{C}$ as in [FIGURE 11]. Differential thermal analysis «DTA» of the third pottery sample showed slight minerals changes in firing temperature from $50.45^{\circ} \mathrm{C}$ to $159.59{ }^{\circ} \mathrm{C}$, the mineral changes increased from $379.01{ }^{\circ} \mathrm{C}$ to $773.37^{\circ} \mathrm{C}$, the stability of the mineral changes ranged from $773.37^{\circ} \mathrm{C}$ to $1000{ }^{\circ} \mathrm{C}$. The results of mineral changes indicated that the firing temperature might have been about $773.37^{\circ} \mathrm{C}$ as in [FIGURE 12].

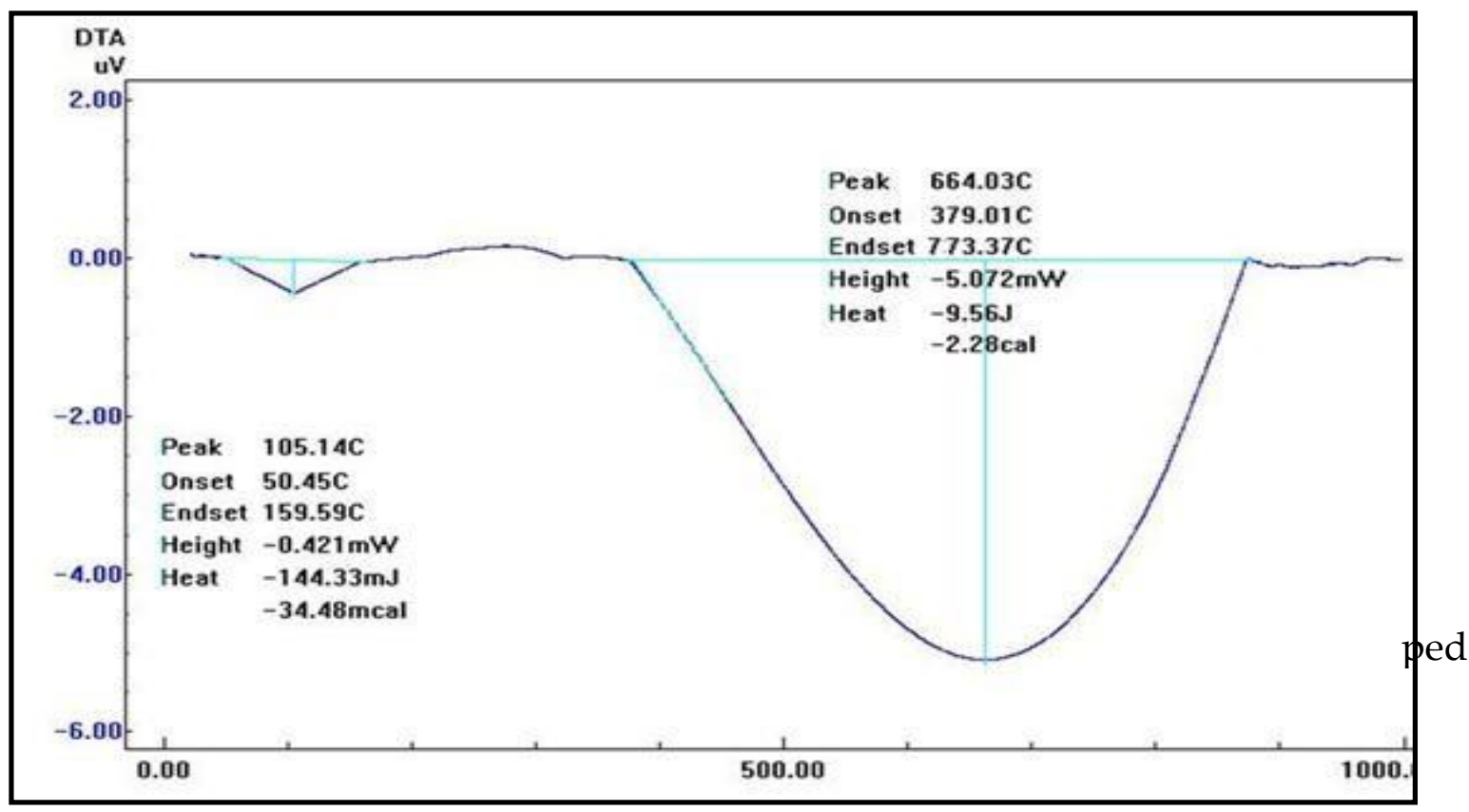

[FIGURE 12]: DTA pattern of the second pottery sample, Tell Abu Yasin, Sharkia,

Egypt

\section{DISCUSSION OF RESULTS}

A visual examination revealed that the pottery pieces in Tell Abu Yasin were shaped by potter wheel and coiling method, which was one of the common formation methods in ancient Egypt ${ }^{27}$. Visual examination also showed presence of a large proportion of soil sediments, and the severity of damage depends on texture of pottery ${ }^{28}$. Pottery suffered stains because the soil was rich in iron oxides ${ }^{29}$, and one of the four pottery pieces suffered from soot due to reduced atmosphere inside the kiln or during functional use ${ }^{30}$.

This pottery often suffered from presence of black core ${ }^{31}$. Pottery pieces suffered from fracture due to mechanical damage of the soil. The severity of the damage depends on type of pottery, soil chemistry, soil column, plants and trees in the soil, or by environmental shocks ${ }^{32}$.

\footnotetext{
27 BOURRIAU 1981: 15.

${ }^{28}$ BUYS \& OAKLEY 1999: 24.

${ }^{29}$ HODGE 1986: 147.

30 WELSBY 1997: 27.

31 SHEPARED 2000: 75.

32 CRONYN 1996: 29.
} 
The visual examination also proved presence of crystallization of salts as shown in [FIGURE 1].

The petrographic study using polarized microscope proved presence of muscovite, orthoclase, pyroxene, and rutile. These minerals are characteristic of the Nile clay confirming that the clay used in pottery manufacture at Tell Abu Yasin was Nile clay. Petrographic study also demonstrated presence of sand, burnt straw «where places of burning of burnt straw have been seen as evidence of the presence of organic matter (burnt straw), but it was burned during firing of pottery inside the kiln», limestone powder and grog (fillers were added during kneading of clay to improve the properties).

Petrographic study also proved existence of surface treatment by applying slip layer, where there was a difference in size of particles of slip layer from size of granules of pottery body. Manufacturer was always assiduous to select fine clay granules in slip layer «surface treatment» ${ }^{33}$. It was evident from the petrographic study that the manufacturer had failed in surface treatment of the pottery plate, it was proven that slip layer was coarse clay grains, with larger size of granules of pottery body itself as in [FIGURE 4].

Petrographic study proved low temperature burning for first pottery vessel; this was confirmed by absence of firing minerals such as gahlenite and diopside, which are glass phases that appear at $850^{\circ} \mathrm{C}$. It showed the quality of burning of the second and third pottery piece; this was confirmed by presence of hematite ${ }^{34}$.

Examination and analysis by scanning electron microscope coupled with X-ray energy dispersion unit (SEM-EDX) confirmed that clay used in the manufacture of pottery at Tell Abu Yasin is Nile clay due to presence of some oxides such as sodium, potassium, calcium, iron and magnesium, which are characteristic of Egyptian Nile clay ${ }^{35}$. It also illustrated presence of calcium carbonate $(\mathrm{C}, \mathrm{Ca})$ as one of the added fillers ${ }^{36}$, in addition to crystallized salts such as halite, carbonates, sulfates and phosphates salts due to burial in saline soil as shown in [FIGURES 5-7]. Examination and analysis confirmed low burning temperature due to the presence of carbon dioxide at a high rate, which reached $4.07 \%$ in some samples ${ }^{37}$.

Moreover, the presence of sulfates salts, where the percentage of sulfur oxide reached between $2.14 \%$ to $7.65 \%$, and the presence of halite salts, where the percentage of chlorine in samples reached between $3.69 \%$ to $6.87 \%$, were noted [FIGURE 8 /A-F].

Analysis by XRD revealed the presence of mica and microcline confirming that clay used in manufacture was Nile clay, it also showed firing temperature of pottery samples. In the first sample, calcite existed as a trace component up to $600-800{ }^{\circ} \mathrm{C}$, and it decomposed completely on firing around $800-850^{\circ} \mathrm{C}$. This indicates that the burning

\footnotetext{
${ }^{33}$ NICLOLSON \& SHAW 2000: 67.

${ }^{34}$ GRIMSHAW 1971: 561.

35 'El-GOHARY et AL 2019: 17611.

36 NAGWA 2016: 22.

${ }^{37}$ MOHAMED 2019: 232.
} 
temperature of the first sample may have been between $700^{\circ} \mathrm{C}$ to $800^{\circ} \mathrm{C}$. XRD. It also confirmed good firing for the second and third piece due to the presence of hematite.

Furthermore, it proved that limestone powder was used as one of the additive fillers due to the presence of calcite in the first sample as in [FIGURE 9/ A]. XRD also illustrated the presence of halite salts in all samples, and the presence of quartz, microcline, albite and halite in the soil sample, which proves that the source of the salts in pottery samples was soil from Tell Abu Yasin in Sharkia as in [FIGURE 9/D].

Differential thermal analysis «DTA» indicated that the firing temperature degree of the samples might have been about $705.26^{\circ} \mathrm{C}$ for the first pottery sample; $782.99{ }^{\circ} \mathrm{C}$ for the second sample and $773.37{ }^{\circ} \mathrm{C}$ for the third pottery sample according to mineral changes as in [FIGURES 10,11,12]

\section{CONCLUSION}

The research has concluded some important results in identifying technological process and damage of pottery objects at Tell Abu Yasin in Sharkia. It proved that the clay used was Nile clay; and additions were sand, burnt straw, grog and limestone powder. Surface treatment was slip layer in samples; while burning atmosphere inside the kiln was reduced for the first pot and oxidized to the second and third pieces. It also illustrated mechanical and physiochemical damage, whether from manufacture defects or effect of burial environment. It has proved the presence of soil sediments, crystallization of salts «carbonate, sulfates, chloride», cracking, peeling, stains and poor physical structure. The research recommends that it should be treated and maintained based on the results of the tests and analyses that have been proven by the researcher in this study.

\section{ACKNOWLEDGEMENT}

I extend my sincere thanks and appreciation to Prof. Dr. Ibrahim Al-Qalla, Dean of Faculty of Archeology for his assistance and encouragement. I also offer my thanks and gratitude to antiquities inspectors in Sharkia Governorate.

\section{HOW TO CITE}

'El-Ghareb, W,. « Microstructure and Damage Assessment of some Ptolemaic Pottery Objects at Tell Abu Yasin in Sharkia, Egypt: Case Study ", Journal of the General Union of Arab Archaeologists, vol.6/1, 2021

Doi: 10.21608/JGUAA2.2020.43613.1036.

walidelghareb@yahoo.com

38 SAcD 2018: 95- 97. 


\section{Walid Kamel ${ }^{\mathrm{C}}$ Ali 'El-Ghareb}

\section{BIBLIOGRAPHY}

ABD 'EL -HAMID, S.M.: «Horbait: Site and History», Annals of the Supreme Council of Antiquities 4, 2007, 668-677.

ABDEMMONIEM, M., NAGLAA, M., WAEL, S.M., ASHRAF Y.E., \& AHMED, A.: «Archaeometry Study of a Polychrome Wooden Coffin from 26 th Dynasty-Egypt», Mediterranean Archaeology and Archaeometry 20/1, 2020, 7-17.

ASHURST, J., \& ASHURST, N.: Practical Building Conservation 2, Brick, Terracotta and Earth, London (Gower Publishing Ltd), 1989,72-73.

BAYAZT, M., ISIK, I., ISSI, A. \&, GENC, E.: «Spectroscopic and Thermal Techniques for the Characterization of the First Millennium AD Potteries from Kuriki-Turkey», Ceramics. International 40, 2014, 14769-14779.

BIRDI, K. S.: «Scanning probe Microscopes» in Application in Science and Technology, 1-15, London, 2003, 1- 2.

BOUKHENOUF, A., \& IAICHOUCHEN, O.: «Study of Terracotta Vaulting Tubes from A new Archaeological Site in Miakou, Algeria», International Journal of Conservation Science 11/ 1, 2020, 51-60.

BOURRIAU, J.: Pottery from Nile Valley before the Arab Conquest, London (Cambridge University Press) $1981,15$.

BUYS, S., \& OAKLEY, V.: The Conservation and Restoration of Ceramics, Oxford (Routledge) 1999, 24 .

CINTEZA, L.O., \& EMANDI, A.: «Trends in Nanotechnology-Based Analytical Methods in Cultural Heritage», International Congress Chemistry for cultural heritage, Istanbul, 2012, 28.

CLIMENT,A.S., CARLOS,J.S., FRANCISCO,J.P.,\& MARIA,L.C.,: «Archaeometric Characterization of the Ceramics from two Celtiberian Hillforts: Preliminary Results», Mediterranean Archaeology and Archaeometry 18/ 1, 2018, 237-253.

CRONYN, J.: The Elements of Archaeological Conservation, Oxford: (Butterworth, Heinemann, ltd.) 1996, 29.

'El-GHARIB, W.: «Study of Treatment and Maintenance of Bronze and Pottery Antiquities Extracted from Excavations», Ma Thesis, Faculty of Archeology/ Cairo University, 2001, 150-155.

'El- GHAREB, W.: «Analytical Study of Some Unfinished Obelisk Quarry Pottery Vessels in Aswan, Egypt, Case Study», American International Journal of Contemporary Research 7/ 4, 2017, 76-77.

'El-GOHARY, M., El-GHAREB, \& W. SAAD, M.: «Damage Quantification of Archaeological Pottery in Sheikh Hamad «Athribis» Sohag Ceramics International Journal 45 /14, 2019, 17611-17619.

FLORIAN, M.: «The Underwater Environment», in Conservation of Marine Archaeological Objects, Edited by PEARSON, C., London (Butterworth-Heinemann) 2000.

GRIMSHAW, R.: The Chemistry and Physics of Clay, London (Wiley-Interscience) 1971, 560 - 561.

HAMITON, D.: Methods of Conserving Archaeological Materials from under Water sites, Texas (Texas University Press) 1998.

HODGE, H. W.: «The Conservation and Treatment of Ceramics in the field», in Situ Archaeological Conservation, Edited by HODGE , H.W., London (Oxford University Press) 1986.

HOGG, S.T., MACPHAIl, D.S., OAKLEY, V., \& ROGER, P.S.: «Modern Instrumental Methods for The Study of The Deterioration of Vessel Glass» in The Conservation of Glass and Ceramics , Edited by TENNENT , N.H., 40-52, London (Maney - Heritage) 1999.

KAMEL, I.: East Delta Region, Cairo: (Supreme Council of Antiquities press) 1981.

MABROUK, M., \& YOSR, E., «Archaeometrical Study of a Rare Embroidered and Appliqued Leather Tapestry from the Safavid Art Works. Part 1: Weaving Fibers and Dyes», Mediterranean Archaeology and Archaeometry 20/1, 2020, 163-171.

MIRTI, P.: «The Use of Colour Coordinates to Evaluate Firing Temperature of Ancient Pottery», Archaeometry $40 / 1,1998,45$.

Mohamed, S. «Analytical Study of Techniques of Archeological Pottery in Sinai with Treatment and Conservation of Some Selected Objects» MA Thesis, Conservation Dept., Faculty of Archaeology/ Fayoum University., :2019. 
MORO, D., ULIAN,G., \& VALDRE, G.: «SEM-EDS Microanalysis of Ultrathin Glass and Metal Fragments: Measurement Strategy by Monte Carlo Simulation in Cultural Heritage and Archaeology», International Journal of Conservation Science 11/1, 2020, 223-232.

NAGWA, S.: «Analytical Study and Conservation of Archaeological Terra Sigillata Ware from Roman Period, Tripoli, Libya», Journal of Applied Science and Technology 2/2, 2016, 22.

NICLOLSON, P. T., \& SHAW, I.: Ancient Egyptian Materials and Technology, London (Cambridge University Press) 2000.

NOUREDDINE, A.: Ancient Egyptian Antiquities Sites from the Earliest Times Until the End of the Dynastic Ages, Part 1, Lower Egypt, Cairo (Dar al-Aqsa for Printing and Publishing) 2018.

PEARSON, C.: «Deterioration of Ceramics, Glass and Stone» in Conservation of Marine Archaeological Objects, edited by PEARSON, C., Oxford (Butter Worth, Heinemann, ltd.,) 2000.

PLENDERLEITH, H. J.: «Problems in the Preservation of monuments» in the Conservation of Cultural Property, London (Oxford University Press) 1968,125.

PRICE, N.S.: «Excavation and Conservation» in Conservation of Archaeological Excavation, Edited by STANLEY PRICE, Italy (ICCROM, Rome) 1984, 4

RIEDERER, J.: «Thin Section Microscopy Applied to the Study of Archaeological Ceramics», Hyperfine Interact 154, 2004, 143-158.

SAcD, M.: «Usage of Nano Materials in the Conservation of Archaeological Pottery: An Experimental Applied Study on Some Excavated Objects from El-Sheikh Hamd-Sohag» MA Thesis Conservation Dept., Faculty of Archaeology/ Sohag University, 2018.

SHEPARED A.O.: Ceramics for the Archaeologists, Washington (institution of Washington. BraunBrumfield, Inc) 1981.

SMITH, A.: Risk Assessment for Object Conservation, Oxford (Butter Worth, Heinemann, ltd.) 1999.

STOLTMAN, J.: «The Role of Petrography in the Study of Archaeological Ceramics», in Earth Sciences and Archaeology, Edited by GOLDBERG, P., HOLLIDAY, V. \& FERRING, C.), New York (Kluwer Academic) 2001, 297-326.

TURKTEKI, S.: «Beycesultan Early Bronze Age I Pottery Group in The Light of New Data», Mediterranean Archaeology and Archaeometry 20/1, 2020, 59-75.

WELSBY, D.: Early Pottery in the Middle Nile Valley in the Pottery in The Making World Ceramic Tradition, London (British Museum Press) 1997. 


\title{
التركيب الاقيق وتقييم تلف بعض الآثار الفخارية البطلمية

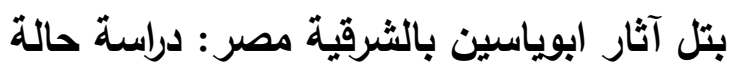

\author{
وليّ كامل على الغريب
}

أستاذ مساعد بقسم الترميم كلية الاثار / جامعة الزقازيق

\begin{abstract}
المخلص
تل آثار ابوياسين من أهم مواقع محافظة الشرقية، ويقع على بعد ؛ كم جنوب شرق ابو كبير و •ـ كم شمال شرق الزقازيق، وهو

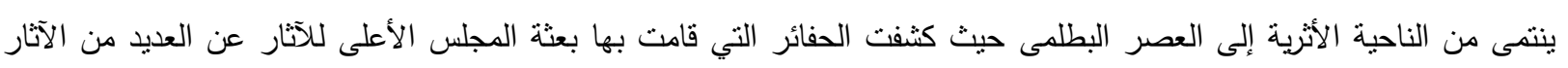
الفخارية المختلفة الأشكال والألوان، فضلا عن العديد من مواقد الأفران المختلفة وجبانة تضم بعض التوائر التوابيت الجرانيتية. وتم إجراء العديد من الفحوص والتحاليل المختلفة مثل الفحص بالميكروسكوب المستقطب Polarized Microscope (PLM) والتحليكانيل

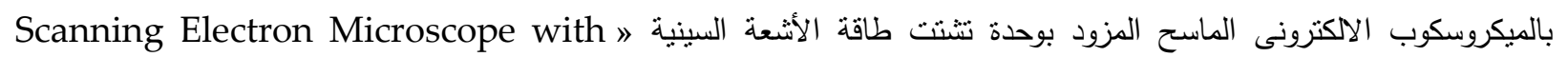
X-Ray Diffraction analysis (XRD) والتحليل بطريقة حيود الأشعة السينية لعnergy Dispersive of X-Ray Unit و التحليل الحرارى Thermal Analysis (DTA). واستخدمت الفحوص والتحاليل المختلفة بغرض التعرف على تكنولوجيا الصناعة لئلة

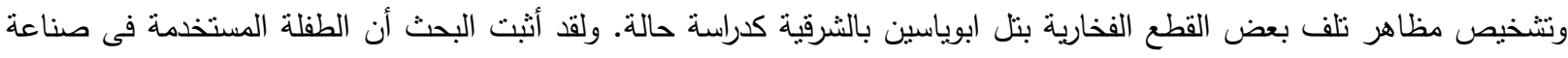

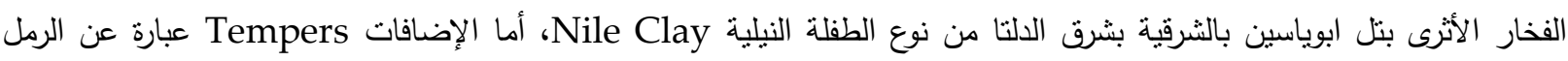

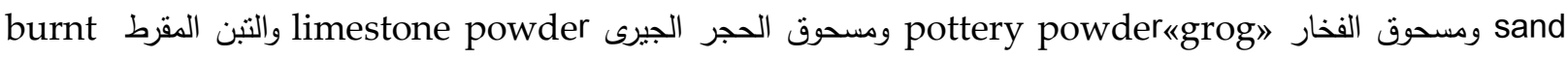
straw من خلال ملاحظة أماكن حرق التنن المقرط اثثاء الحرق للفخار داخل الفرن، وتقنية التشكيل المستخدمة هى تقنية التشكيل

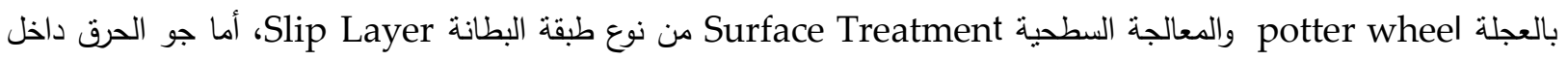
الفرن كان جوا مختزلا للقطعة الأولى ومؤكسدا للقطعة الثانية والثالثة. كما أثبت البحث أيضا أن معظم الآثار الفخارية بتل ابوياسين بالثرقية بشرق الدلتا تعانى من التلف الفيزيوكيميائى Physiochemical damage مثل رواسب التربة soil sediments،

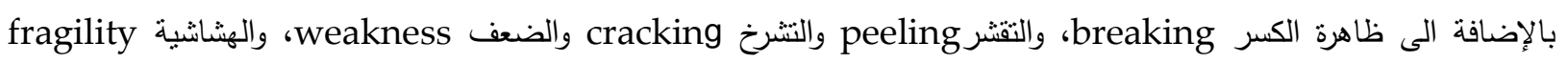

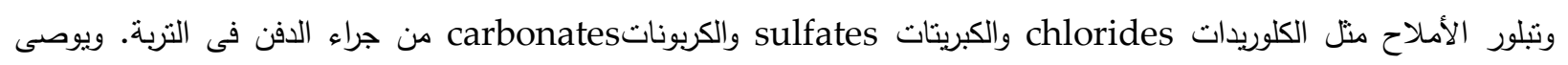
البحث بترميم وعلاج وصيانة تلك القطع الفخارية بناءاً على نتائج الفحوص والتحاليل وتقييم مظاهر التلف للقطع الفخارية بالموقع الأثرى

الكلمات الدالة: الفخار ، الطفلة، الإضافات، المعالجة السطحية، طبقة البطانة، جو الحرق، التشرخ، التقتر • 